\title{
Correlation between the Rate of Water Intake of Tropical Soils at hourly intervals to the 8th hour
}

\author{
M. A. Lugo-López, J. Juárez, Jr., and Raúl Pérez Escolar ${ }^{1}$
}

\section{INTRODUCTION}

Water intake measurements of soils are of paramount importance in planning and designing irrigation and drainage systems as well as in developing soil management and conservation practices. The rate of water infiltration under field conditions is generally considered to be one of the most realistic indices of water intake rates. Available data from tropical soils is rather scarce in this respect.

Methods for measuring soil infiltration by water under field conditions are laborious and time-consuming. They generally take from 4 to 8 hours. This is because the rate of moisture intake of the soil at the beginning of the test depends on highly variable soil conditions. As the test progresses, the rate of moisture intake approaches, as a limit, the rate of water intake of the horizon of the soil with minimum water intake capacity.

This paper reports the results of statistical studies aimed at determining the correlation between soil water intake rates at hourly intervals to the 8th hour. The results may be useful in reducing the time required for conducting field infiltration tests, without appreciably affecting adversely the precision of the data that could be obtained by using a suitable equation based on data from shorter time intervals.

\section{PREVIOUS WORK}

Free, et al. $(4)^{2}$ published considerable data in 1940 on the relative infiltration and related physical characteristics of certain soils of the United States. They found high correlation coefficients between amounts of infiltration during various time intervals. These values ranged from 0.854 between the 0-15 minute period of the initial run ${ }^{3}$ and the 120-180 minute period of the wet run to 0.997 between the 120-180 minute wet run and the 0-180 minute wet run (4).

1 First two, Soil Scientists, and Associate Soil Scientist, respectively, Agricultural Experiment Station, Mayagüez Campus, University of Puerto Rico, Río Piedras, P.R.

The authors wish to express their sincere appreciation to Mrs. Carmen Báez de Chao and Mr. Mariano Antoni for their valuable help in the statistical analysis of the data used in the preparation of this paper.

2 Numbers in parentheses refer to Literature Cited, p. 575.

8 The standard manner of applying water to the soil was to make initial and wet runs of a 3-hour duration each, with about 24 hours between the runs. 
In Puerto Rico, a research program was conducted to develop basic information on the infiltration rate of tropical soils. Bonnet and TiradoSulsona ( $(3)$ published some of the first data from soils of southwestern Puerto Rico in 1950. Bonnet an Lugo-López (1) published additional infiltration data during the same year as part of their studies on a proposed south-central irrigation project area. Lugo-López, et al. (5) in 1953 published more data in their study of the soils of the Island of Vieques. Data on the rate of infiltration of Oxisols and Ultisols also was published by Bonnet and Lugo-López (2). Other data was subsequently. published by Martínez and Lugo-López (9) and Lugo-López, et al. $(7,8)$.

More recently, Lugo-López, Juárez, Jr., and Bonnet (6) prepared a rather comprehensive report summarizing the bulk of the data obtained in the study of the relative rate of infiltration of Puerto Rico soils, most of which was not previously published elsewhere.

\section{PROCEDURE}

Infiltration tests were run under field conditions in selected soils including 57 of the major soil series of the Island. They included seven of the 10 orders recognized in the 7th approximation of the new soil classification system (6). Each test run was in quadruplicate at each site. Tests for most of the soil series were conducted at more than a single location for a total of 740 individual tests. The tests were run using the buffer compartment method as outlined by Nelson and Muckenhirn (10).

For the study herein reported all the available data (6) .was pooled together and the correlations were determined between the rate of infiltration at the 8th hour and the rates at each of the preceding individual 7-hour periods. The correlation coefficients and the coefficients of determination were calculated. Linear equations were developed in each case to express the relationship.

\section{RESULTS AND DISCUSSION}

A summary of the data on mean infiltration rates for the 740 tests is given in the following tabulation:

$$
\begin{gathered}
\text { Time interval } \\
\text { (Minstes) } \\
0-60 \\
60-120 \\
120-180 \\
180-240 \\
240-300 \\
300-360 \\
360-420 \\
420-480
\end{gathered}
$$

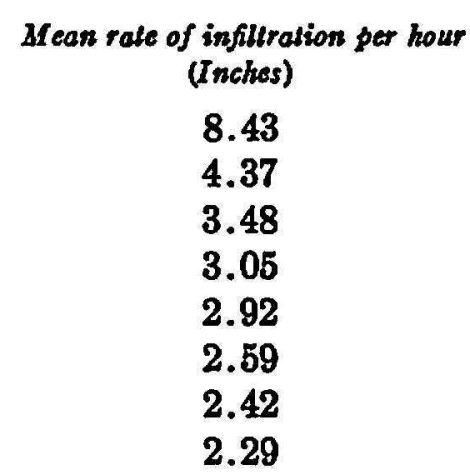

In general, there is a rapidly changing rate of infiltration at the start, 
particularly during the initial two time intervals, but a reduction and a slightly declining rate of infiltration occurs thereafter. (fig. 1). The range of mean infiltration rates, by soil orders, have been published previously (6).

Correlations between the 8th hour infiltration rate and the various preceding 1-hour intervals have shown a high degree of relationship. The correlations, all highly significant, are shown in the following tabulation:

$\begin{array}{cc}\begin{array}{c}\text { Time interval for witich inflltration rates are correlated } \\ \text { with the sith hour rale } \\ \text { (Afinules) }\end{array} & \text { Value of r } \\ 0-60 & \\ 60-120 & 0.796 \\ 120-180 & .848 \\ 180-240 & .917 \\ 240-300 & .943 \\ 300-360 & .938 \\ 360-420 & .970 \\ & .987\end{array}$

The high correlation coefficients between measured rates of infiltration at various time intervals and the 8th hour infiltration rate indicate that rates for all time intervals can be used in estimating the infiltration rate at the 8th hour with a high degree of precision.

Using data from the first time interval (0-60 minutes), only 63 percent of the variability in the 8th hour infiltration rate can be explained. This percentage, however, increases to 72,84 , and 89 when using data from the successive three time intervals, respectively. It increases further as the 8 th hour is approached (fig. 2).

The relatively low portion of the variability (as compared with the others) that can be explained with data from the first hour can be probably accounted to variations in the initial field moisture content of the soil. These differences tend to be minimized as time goes by and infiltration then really depends more on the properties of the soil profile.

It is suggested that the rate of water infiltration at the 8th hour be estimated by use of the following equation:

$$
Y=0.38+0.55 X
$$

where $Y=$ rate of water infiltration during the 8th hour and $X=$ rate of water infiltration during the 3 rd hour.

Similar equations may be applied if desired to use other time intervals as a basis for estimating the 8th hour infiltration rate. However, the evidence seems to indicate that there is no need to conduct field infiltration 
tests for any practical purpose beyond the third hour. Even the first and second bour data can provide reliable estimates.

\section{SUMMMARY}

Statistical studies of data obtained from $\mathbf{7 4 0}$ field infiltration tests are presented herein. In general, there is a rapidly changing rate of infiltration

9 .

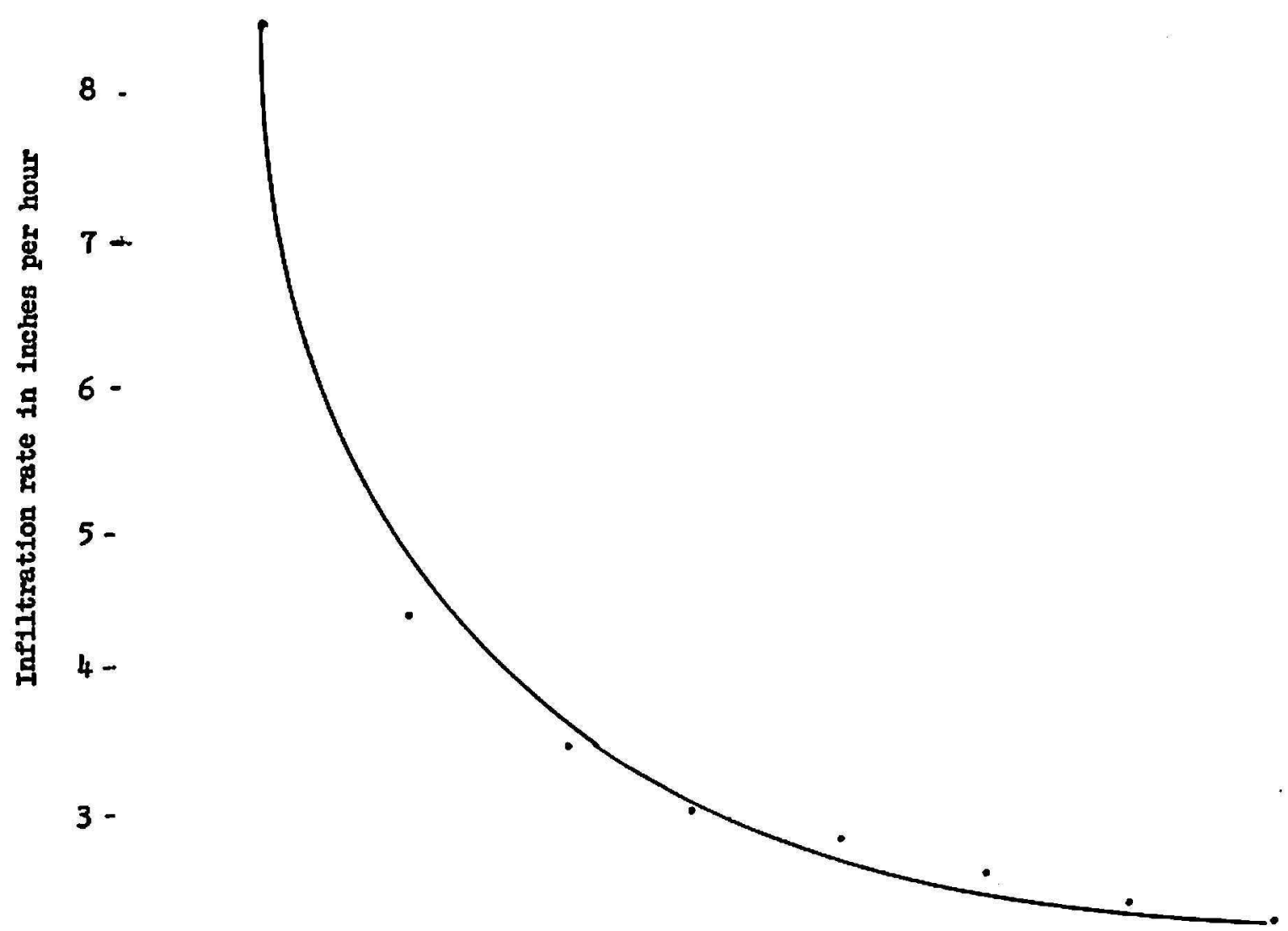

2 -

1.

\begin{tabular}{|c|c|c|c|c|c|c|c|}
\hline $60^{\circ}$ & 120 & 180 & 240 & 300 & 360 & 420 & 480 \\
\hline
\end{tabular}

FIG. 1. Showing changes in the rate of infiltration with time.

at the initial hour of the test, but a declining rate is registered soon after. Correlations between the 8th hour infiltration rate and the preceding 1-hour intervals are highly significant. A linear relationship is suggested to estimate 
the 8th hour infiltration rate on the basis of the third hour measurements. This may save time and expense without significant reduction in precision.

\section{RESUMEN}

En este trabajo se presentan los estudios estadísticos de los datos obtenidos de 740 pruebas de infiltración de agua, en ciertos suelos, realizadas bajo condiciones de campo. En términos generales, la velocidad de la

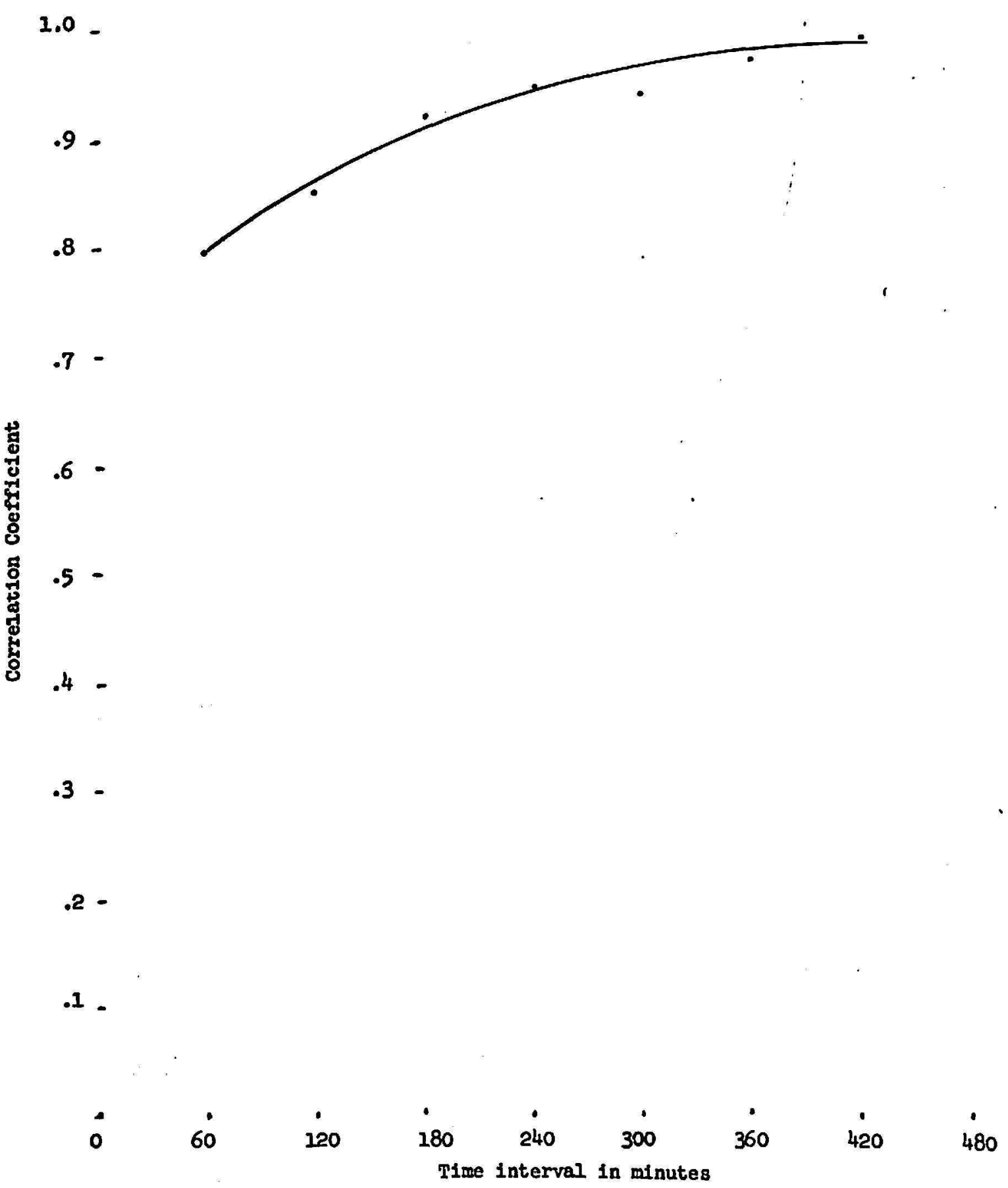

Fic. 2.-In predicting the 8 th hour infiltration rate based on data from previous time intervals, precision increases as the 8 th hour is approached. 
infiltración varía rápidamente durante las primeras horas de la prueba, pero luego estos cambios van disminuyendo progresivamente. Se encontraron correlaciones altamente significativas entre la velocidad de la infiltración a la octava hora de iniciada la prueba y la que ocurre durante los intervalos de una hora, precedentes. Se sugiere el uso de una relación lineal para poder estimar la infiltración a la octava hora, a base de la medida tomada a la tercera hora. Esto economizaría tiempo y disminuiría el costo de las pruebas, sin que se afectara marcadamente la precisión de los datos.

\section{LITERATURE CITED}

1. Bonnet, J. A., and Lugo-Iópez, M. A., Soil studies in the projected Coamo irrigation area, Univ. P.R. Agr. Exp. Sta. Bull. 88, 1950.

2. - and- The rate of infiltration of lateritic soils, J. Agr. Univ. P. R. $\$ 6$ (2): 161-66, 1952.

3. Bonnet, J. A., and Tirado-Sulsona, P., Soil studies in Lajas Valley, Univ. P.R Agr. Exp. Sta. Bull. 86, 1950.

4. Free, G. R., Browing, G. M., and Musgrave, G. W., Relative infiltration and related physical characteristics of certain soils, USDA Tech. Bull. 729, 1940.

5. Lugo-López, M. A., Bonnet, J. A., and Garcia, Jean, The soils of the Island of Vieques, Univ. P.R. Agr. Exp. Sta. Bull. 108, 1953.

6. Lugo-Lopez, M. A., Juśrez, Jr., J., and Bonnet, J. A., The relative rate of infiltration of Puerto Rican soils, J. Agr. Univ. P.R. 62 (3): 233-40, 1968.

7. Lugo-Lopez, M. A., Landrau, Jr., P., and Samuels, G., The handling of sugarcane trash. II: Effects of various practices on soil properties, J. Agr. U.niv. P.R. $\$ 6$ (3): 240-5, 1952.

8. Lugo-López, M. A., Martínez, M. B., and Riera, A. R., Morphological and physicochemical properties of various tropical soils from east-central Puerto Rico J.Agr. Univ. P.R. $\$ 6$ (2): 167-78, 1952

9. Martínez, M. B., and Lugo-Iópez, M.A., Tillage tests. I: Effect of subsoiling and mole drainage upon the minimum infiltration capacity of a heavy clay soil of the Tropics, J. Agr. Univ. P.R. 86 (2): 179-85, 1952.

10. Nelson, L. B. and Muckenkirn, R. J., Field percolation rates of four Wisconsin soils having different drainage characteristics. J. Amer. Soc. Agron. 39. (11): 1028-36, 1941. 